\title{
Placer scheelite and gold from alluvial sediments as indicators of primary mineralisation - examples from SW Poland
}

\author{
Stanisław Zbigniew MIKULSKI ${ }^{1, *}$ and Jan WIERCHOWIEC ${ }^{2}$ \\ 1 Polish Geological Institute - National Research Institute, Rakowiecka 4, 00-975 Warszawa, Poland \\ 2 Faculty of Geology, University of Warsaw, Żwirki i Wigury 93, 02-089 Warszawa, Poland
}

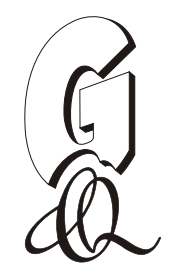

Mikulski S.Z. and Wierchowiec J. (2013) Placer scheelite and gold from alluvial sediments as indicators of primary mineralisation - examples from SW Poland. Geological Quarterly, 57 (3): 503-514, doi: 10.7306/gq.1107

\begin{abstract}
Detailed morphological studies of detrital scheelite and gold grains from clastic Cenozoic deposits (alluvial and eluvial-colluvial) in two selected areas of Lower Silesia allowed description of their specific features (size, roundness, lustre, and lack or remnants of primary intergrowths with other minerals, and for gold also of the flatness index). This allows estimation of the length of hydrodynamic transport and distance from the source area. Such features are also an important tool in determining the source of ore mineralisation and of establishing the parent area for detrital accumulations. Moreover, electron microprobe (EMPA) investigation of detrital gold and scheelite allowed recognition of the internal structure and chemical composition of these minerals. The gold grains commonly revealed zonal structures due to chemical supergene gold mobility recognized in nearly all pan-concentrate samples studied.
\end{abstract}

Key words: gold, scheelite, placer, prospecting, Lower Silesia, Sudetes.

\section{INTRODUCTION}

The morphology and texture of detrital ore minerals from pan-concentrate samples collected from a range of sediments in a drainage system (active channel, alluvial, eluvial and colluvial sediments) may be a useful means of determining the distance to and type of primary (bedrock) source mineralisation (Loen, 1995; Chapman et al., 2000; Townley et al., 2003; Chapman and Mortensen, 2006; Wierchowiec, 2006; Nikolaeva and Yablokova, 2007; Dill et al., 2009). Several examples of such study of transport of detrital gold grains have been described (e.g., Boyle, 1979; Tishchenko, 1981; Giusti, 1986; DiLabio, 1990; Hérail et al., 1990; Knight et al., 1999; Youngson and Craw 1999; Wierchowiec, 2002).

The morphology of detrital gold grains changes during mechanical transport because gold is very soft (hardness 2.5-3) and usually survives long distance transport in streams. In contrast, scheelite which is harder (4-5) but also brittle, does not survive long distance transport in stream sediments and also changes its morphology (e.g., Stendal, 1978; Hallenstein et al., 1981; Saxby and Fletcher, 1986; Petersen and Stendal, 1987). Detailed studies of changes in the morphology of both minerals during fluvial transport, despite their differences in physical properties, may be strong indicators of nearby primary mineralisation in bedrocks. We present results of microscopic studies of detrital

\footnotetext{
* Corresponding author, e-mail: stanislaw.mikulski@pgi.gov.pl
}

Received: April 18, 2013; accepted: May 28, 2013; first published online: June 27,2013 scheelite and gold from two sites in the Lower Silesia region of SW Poland (Fig. 1). Placer gold in Lower Silesia was eroded from auriferous quartz veins (e.g., Grodzicki 1963, 1969). In this region, numerous orogenic gold-bearing quartz \pm polymetallic sulfide veins are hosted by Lower Paleozoic metamorphosed volcanic-sedimentary rocks (e.g., Mikulski, 1996, 1998, 2005, 2007, 2011). These rocks were intruded by Variscan igneous rocks distributed both in the Sudetes and in the Fore-Sudetic Block. Examples of detrital scheelite presented in this paper were eroded from hydrothermal contact metasomatic and vein type tungsten mineralisation which formed during Variscan plutonism (Mikulski, 2000). Post-orogenic uplift of the Variscan orogen during the Mesozoic and Cenozoic exposed numerous veins with primary mineralisation which were subject to different types of mechanical and chemical disintegration (e.g., Wierchowiec, 2010, 2011; Grodzicki, 2011).

\section{METHODS AND MATERIALS}

Samples of detrital scheelite and gold presented in this paper were collected independently by both authors using the method adopted in the 1980s by the Polish Geological Institute during detailed geochemical and heavy mineral prospecting in selected areas of Lower Silesia (Kanasiewicz et al., 1990). Heavy mineral pan-concentrate samples were collected from stream sediments in active channels at two localities: (1) the Brodek River in the southern part of the drainage system of the Kłodzko-Złoty Stok Granite Pluton near Droszków (Fig. 2), and (2) the Wierzbiak River, which drains the Wądroże Wielkie region in the Fore-Sudetic Block. Active stream sediments from 


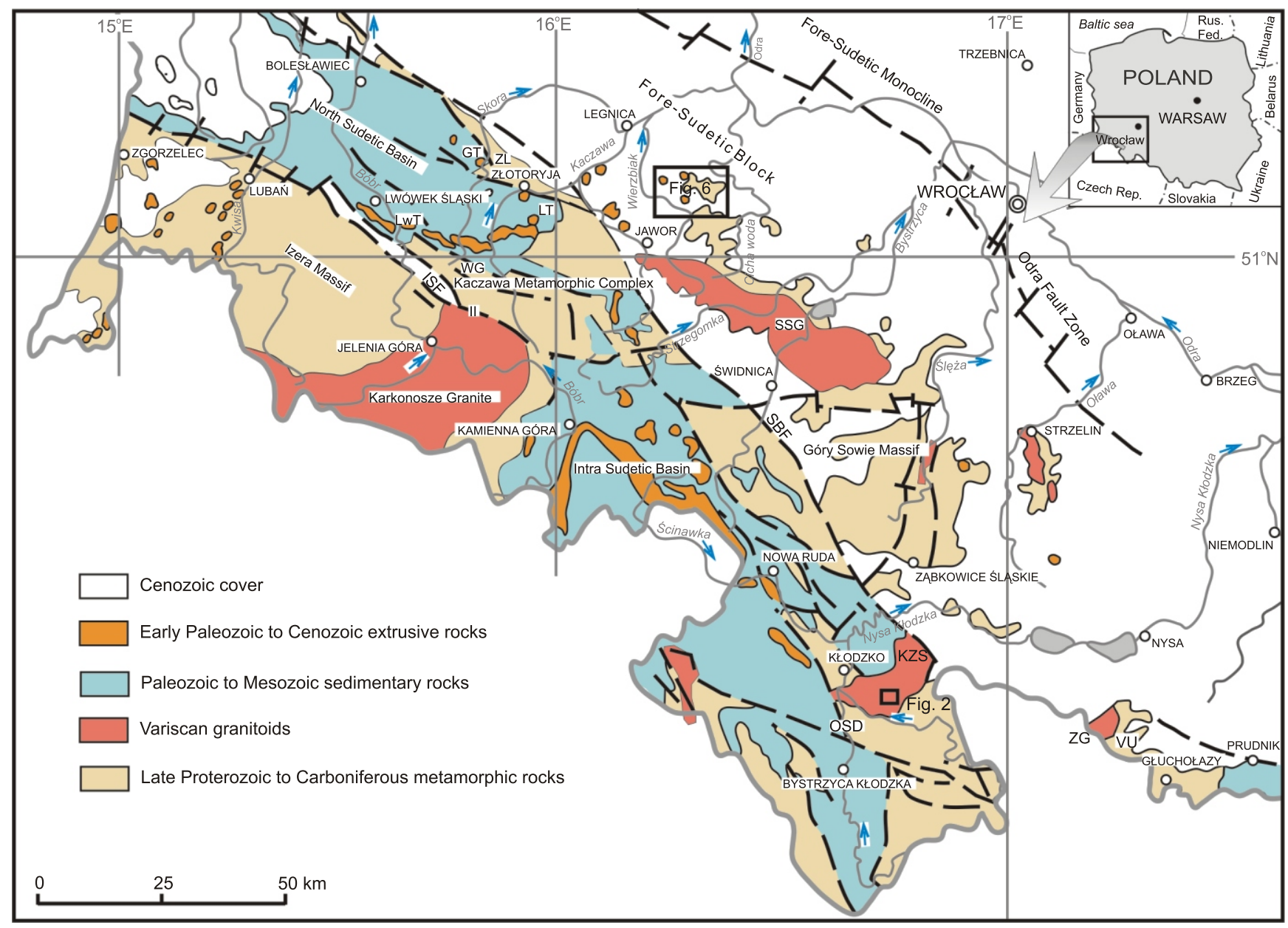

Fig. 1. Generalized geological-structural map of Lower Silesia (after Sawicki and Teisseyre, 1978) with location of the sampling areas

GT - Grodziec Trough; ISF - Intra-Sudetic Fault Zone; KZS - Kłodzko-Złoty Stok Granite Pluton; LT - Leszczyna-Jerzmanice Trough; LwT - Lwówek Trough; OSD - Orlica-Śnieżnik Dome; SBF - Sudetic Boundary Fault; SSG - Strzegom-Sobótka Granite Pluton; VU - Vrbno Unit; WG - Wleń Graben; ZG - Žulova Granite; ZL - Złotoryja-Luboradz Unit

0.1 to $0.5 \mathrm{~m}$ of depth were sampled. Samples of variable volume from 0.01 to $0.1 \mathrm{~m}^{3}$ were sieved and panned with use of the "Siberian" pan, which is made of rust-free steel, has a diameter of ca. $22 \mathrm{~cm}$ and is $8 \mathrm{~cm}$ in depth. A sluice box was also used for gold sampling in the Wierzbiak River. It was thoroughly washed with new matting inserted for each sample to avoid contamination between samples. A total of 22 panned scheelite concentrates were collected from the upper parts of the Brodek River (Mikulski, 2000) and 10 panned gold samples were collected from the Wierzbiak River (Wierchowiec, 2010). Besides, a heavy mineral concentrate was also made from rocks hosting primary scheelite mineralization of veinlet-impregnation type collected near Droszków. Rock samples of weight ca. 1 kg were first processed by mechanical crushers, than small pieces of rock were disaggregated using electric pulse disaggregation and finally scheelite grains were picked by hand under a UV lamp. Sample preparation included separation of each panned concentrate in the heavy liquid bromoform with a specific gravity of 2.89, and manual separation of several fractions including: (1) magnetic, (2) electromagnetic I and II (3) and non-magnetic. Separation was performed using a Ventouse magnet (made by Allevard Ugine, France) followed by optical identification of minerals. All visible scheelite and gold grains were separated from reprocessed samples by hand-picking under a binocular micro- scope and weighed. Scheelite was simply identified by use of short wave (2540 A) UV light by Raytech \#10-070 model. Scheelite and gold contents were expressed as the number of grains counted in the sample per cubic meter (Kanasiewicz, 1982). The size of scheelite grains studied range from $<0.2$ to $3 \mathrm{~mm}$ and of gold grains from 0.05 to $1.5 \mathrm{~mm}$. Gold grains $<0.2 \mathrm{~mm}$ in size are described in the text as fine and those $>0.8 \mathrm{~mm}$ in size as coarse. All grains were weighed and divided into specific grain size fractions. Roundness of gold grains ( 6 categories from I = very angular to $\mathrm{VI}=$ well-rounded $)$ was assessed using the class system of Powers (1953). Where the long (a), intermediate (b), and small (c) axes of gold particles were measured under a low-powered binocular microscope fitted with a micrometer eyepiece, in order to calculate the Cailleux flatness index (F.I. = $(a+b) / 2 c$; Cailleux, 1945). The Cailleux index is a measure of the transport-induced mass redistribution (i.e., shape change) of gold grains by progressive hammering and/or folding in the fluvial system. It has been used for Bolivian (Hérail et al., 1990) and New Zealand (Youngson and Craw, 1999) placer gold studies.

Additionally, gold grains representing different morphologies were analysed under SEM (scanning electron microscope), a Jeol JSM-6380LA in energy-dispersive mode (EDS Link Analytical ISIS). Operating conditions were: $20 \mathrm{kV}$ acceler- 

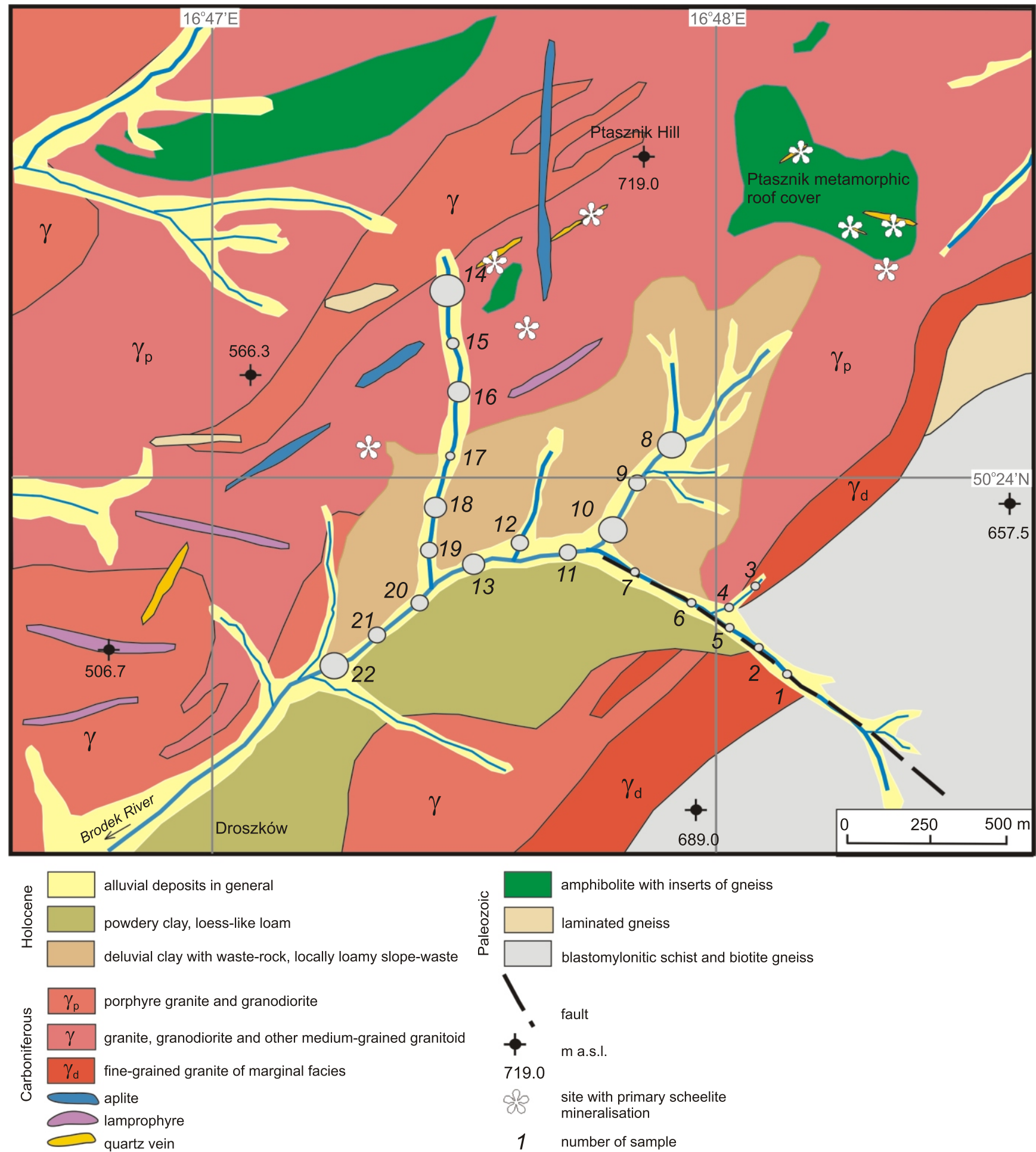

Content of detrital scheelite in alluvial sediments $\left[\right.$ in $\left.\mathrm{g} / \mathrm{m}^{3}\right]$
○ $\quad 0.001-0.332$
$0.333-1.065$
1.066-2.925
$2.926-4.785$
$4.786-6.64$

Fig. 2. Geology of the Ptasznik Hill metamorphic rocks of the Kłodzko-Złoty Stok Granite Pluton (after Cwojdziński, 1977) with its drainage system and sites of primary scheelite mineralisation and location of pan-concentrate stream sediment samples 
ating voltage, $5 \mathrm{~mm}$ spot size, and $6 \mathrm{nA}$ sample current. The ZAF-4 correction program was applied. Quantitative chemical analyses (EMPA) of gold grains were made by use of a CAMECA SX100 electron microprobe. Operating conditions for EMPA were: $25 \mathrm{kV}$ accelerating voltage, $2 \times 10^{-8} \mathrm{~A}$ primary beam current, $25 \mathrm{sec}$ counting time, and detection limits (wt.\%) for $\mathrm{Au}-0.121$ and for $\mathrm{Ag}-0.033$. Scheelite grains were analyzed by use of a Jeol JSM-840A with EDS. Operating conditions were: $\mathrm{U}=20 \mathrm{kV}, \mathrm{I}=6 \times 10^{-9} \mathrm{~A}, \mathrm{t}=10 \mathrm{~s}, \varphi=5 \times 10^{-6} \mathrm{~m}$. Natural mineral standards and the $Z A F-4$ were used.

\section{GEOLOGICAL SETTING OF THE SCHEELITE MINERALISATION FROM THE PTASZNIK METAMORPHIC ROOF COVER}

The first area studied is located on the Kłodzko-Złoty Stok Granite Pluton (KZS) which constitutes the eastern prolongation of the Saxothuringian Zone within the Central European Variscides on the northern margin of the Bohemian Massif. The KZS outcrops over an area of $120 \mathrm{~km}^{2}$ (Fig. 2). Geochemical and petrographic studies of the KZS intrusive indicate that it is composed mostly high-K, metaluminous, biotite- and hornblende-rich granitoids of various compositions ranging from granodiorite to monzonite. They contain rare xenoliths of metamorphic rocks and abundant mafic enclaves (e.g., Wierzchołowski, 1976; Lorenc, 1994). The KZS pluton represents an I-type magma mixed with partial melts of continental crust. The geochemical heterogeneity of the granitoids is typical of rocks originating from hybrid magmas. SHRIMP zircon $\mathrm{U}-\mathrm{Pb}$ dating of igneous rocks from the KZS indicates that the granitoids and lamprophyres were intruded in the Early Carboniferous (Mid-Visean) from ca. 340 to $331 \mathrm{Ma}$ (Mikulski et al.,
2013). The magmatic episode lasted $8.7 \pm 3.6 \mathrm{Ma}$ and was concurrent with orogenic uplift and cooling. Subsequent magmatic activity formed dykes of melanocratic and leucocratic rocks, that was followed by hydrothermal activity responsible for quartz veins formation. Strong contact metasomatic processes at the same time were responsible for the local metasomatic mineralisation (scheelite-titanite) such as that at the Ptasznik prospect (Mikulski, 2000) and auriferous skarn mineralisation in the Złoty Stok Au-As deposit (Mikulski and Speczik, 2008). The roof of the KZS pluton is preserved as irregularly distributed relics of the Early Paleozoic volcanic and sedimentary rocks related to the Laqdek-Śnieżnik Metamorphic Complex (Wojciechowska, 1975). The sedimentary rocks enclose mafic and felsic intercalations. They were regionally metamorphosed to amphibolite facies, and then contact metamorphosed by the KZS intrusion. In the region, Late Carboniferous melanocratic and leucocratic veins such as lamprophyres, aplites and quartz \pm feldspar (K) commonly occur.

Primary scheelite mineralisation was found during heavy mineral and geochemical sampling of the Ptasznik metamorphic cover complex in the SE part of the KZS. The mineralisation crops out over an area of $0.4 \mathrm{~km}^{2}$ (Figs. 2 and 3). Scheelite mineralisation forms stockworks, disseminations or veinlets within strongly metasomatised pyroxene amphibolites, amphibole gneisses or quartz \pm feldspar (K) veins (Mikulski, 1999, 2000). Scheelite associated with titanite forms automorphic grains from 0.1 to $5 \mathrm{~mm}$ in size (average about $1 \mathrm{~mm}$ ) in stockworks and veins. In the country rock, scheelite grains fill voids, are xenomorphic and 0.1 to $0.3 \mathrm{~mm}$ in size. Concentrations of tungsten in mineralised rock samples reach up to $\sim 0.3$ wt. $\% \mathrm{WO}_{3}$ and of gold up to $18 \mathrm{ppm}$ (Mikulski, 2000).

The area is drained by the Brodek River catchment. Its tributaries drain a high-relief area composed of granites, porphyry, migmatitic gneisses and amphibolites (Fig. 3). In their lower

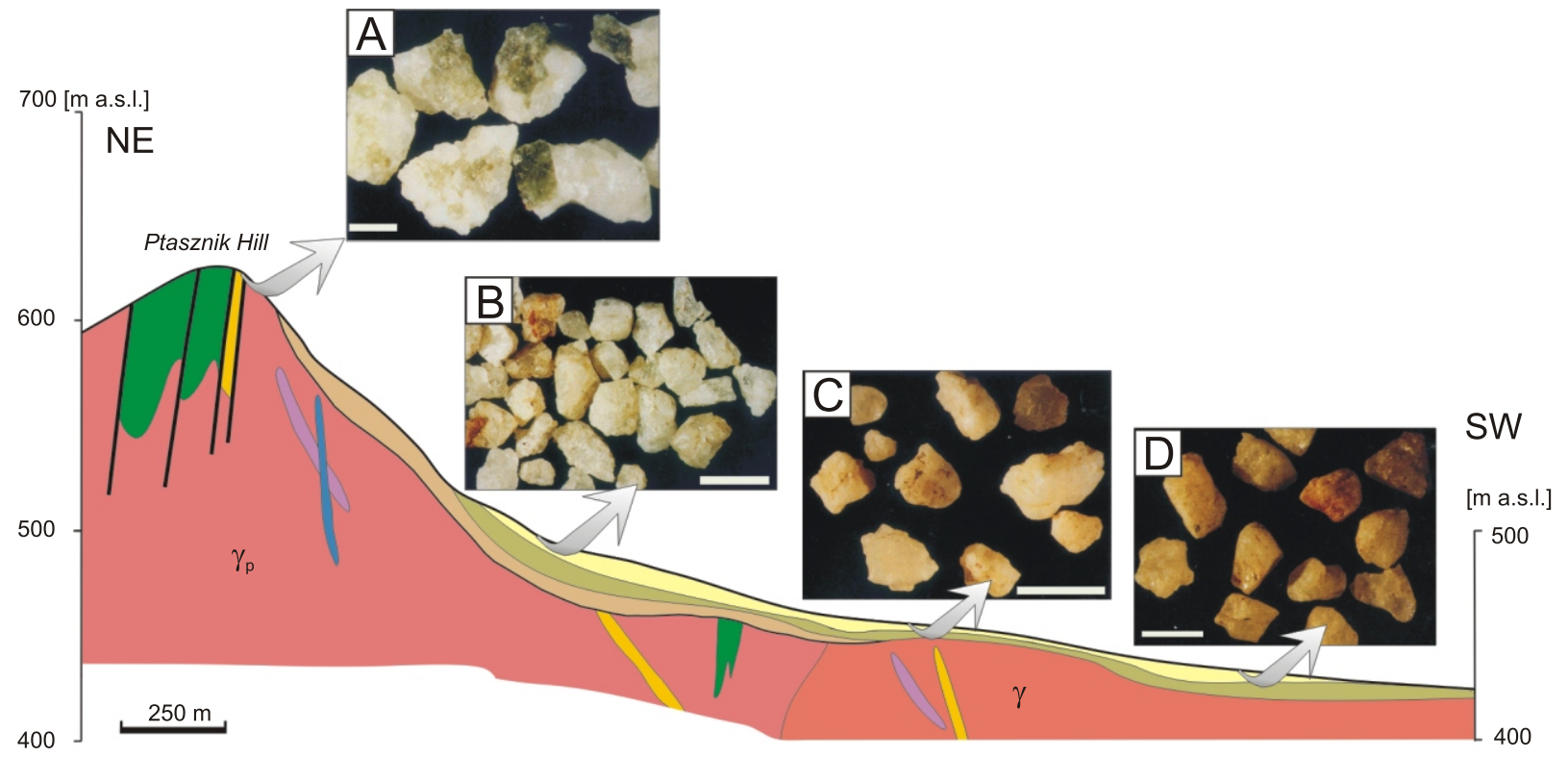

Fig. 3. Schematic geological cross-section of the southern slopes of Ptasznik Hill along the Brodek River channel with photograph inserts of scheelite grains from heavy mineral samples

A - typical angular grains of scheelite with titanite (dark grey) intergrowths and adamantine lustre from panned concentrate of crushed bedrock; $\mathbf{B}$ - in alluvial sediments detrital scheelite grains $<1 \mathrm{~km}$ from the bedrock source are subangular and usually without any intergrowths with other minerals, the percentage of larger scheelite grains $(>1 \mathrm{~mm})$ in panned concentrates dramatically decreases as compared to the near-bedrock sample; C, D - subangular to subrounded detrital scheelite in alluvial sediments collected $>2.0 \mathrm{~km}$ from the source area have lost their glassy lustre and taken on a matt surface appearance, and are covered by beige-yellow coating of clay-like minerals, fine-grained scheelite $(<0.4 \mathrm{~mm})$ dominates $(\sim 80 \%)$ the samples $>2.0 \mathrm{~km}$ down stream; all scale bars $1 \mathrm{~mm}$; other explanations as in Figure 2 
parts, the modern streams drain the Cenozoic deluvial clays with rock wastes, loess-like loams and Quaternary alluvial and glacial deposits.

\section{MINERALOGICAL AND STATISTICAL CHARACTERISTICS OF PLACER SCHEELITE FROM THE SOUTHERN SLOPES OF PTASZNIK HILL}

The study area is located in the upper part of the Brodek River and its tributaries, northeastwards of the village of Droszków. A total of 22 heavy mineral samples were collected from the active alluvial sediments along a distance of $6 \mathrm{~km}$. The heavy mineral concentrates were divided into six granulometric classes $(<0.2 \mathrm{~mm}$ 0.2-0.4 mm; 0.4-0.6 mm;0.6-0.8 mm;0.8-1.0 mm; >1.0 mm) for morphometric studies (Fig. 4). Scheelite concentrations were calculated in gram per cubic metre $\left(\mathrm{g} / \mathrm{m}^{3}\right)$. An average arithmetic concentration of scheelite in all 6 granulometric classes added together in alluvial sediments of the Droszków area is low $\sim 2.2 \mathrm{~g} / \mathrm{m}^{3}$. However, this value is almost twenty-times higher than the regional background value in the Złote Mountains (Mikulski, 2000). The highest concentration of scheelite $\left(6-8 \mathrm{~g} / \mathrm{m}^{3}\right)$ occurs in samples collected near the spring of the Brodek stream and its tributaries. Concentrations of scheelite averaging $>3 \mathrm{~g} / \mathrm{m}^{3}$ were recognized $2.5 \mathrm{~km}$ distance downstream. In the upper parts of the stream, scheelite occurs mostly as angular or subrounded grains in fine $(<0.4 \mathrm{~mm})$ and coarse $(>1.0 \mathrm{~mm})$ fractions (Fig. 5). Fine $(<0.4 \mathrm{~mm})$ and angular scheelite grains have glossy or an adamantine lustre and pristine edges of well-developed crystals (e.g., tetragonal bi-pyramids). Grains with tabular habit are also present. Some scheelite grains have eroded surfaces, covered by a thin yellow-beige crust. Larger grains (1-2 mm in size) reflect the original size of the primary scheelite in bedrock. Moreover, the larger scheelite grains have a similar chemical composition to scheelite from the primary mineralisation (e.g., $\mathrm{WO}_{3}-81.3 \mathrm{wt} \%, \mathrm{CaO}-$ 18.4 wt. $\%, \mathrm{MoO}_{3}<0.4$ wt. $\left.\%\right)$. The content of coarse-grained scheelite (>0.8 mm fraction) in stream sediments is low $(0.5 \%)$ but higher than in other areas of the Złote Mountains (Mikulski, 2000). Scheelite grains $<0.2 \mathrm{~mm}$ in size comprise 40 to $90 \%$ of the total scheelite content of stream sediment samples in this region. Heavy mineral concentrates also contain other minerals including ilmenite (up to $30 \mathrm{~g} / \mathrm{m}^{3}$ of alluvial sediments), rutile, titanite, hema- tite, magnetite, spinels, arsenopyrite, pyrite, cassiterite (single grains) and rare platy gold grains ( 0.1 to $0.4 \mathrm{~mm}$ in size). The accessory minerals to the scheelite mineralisation include barite, fluorite, corundum, andalusite, disthene (kyanite), sillimanite and up to $60 \mathrm{~g} / \mathrm{m}^{3}$ of zircon.

\section{MORPHOMETRIC FEATURES OF PLACER SCHEELITE FROM STREAM-CHANNEL SEDIMENTS}

The comparison of placer scheelite from stream-channel sediments with that from the artificial heavy mineral concentrate (made from rocks hosting primary scheelite mineralisation) allowed for the following conclusions. Numerous intergrowths of scheelite with other minerals (e.g., titanite, quartz) observed in the bedrock concentrate are rare in the alluvial sediments (Fig. 3). Most of scheelite grains subjected to a short $(\sim 1 \mathrm{~km}$ from the source) mechanical transport are subrounded. Angular edges of scheelite crystals developed as tetragonal column-like or bi-pyramid features seen on scheelite grains in bedrock are not visible on grains in stream sediments. Fluid inclusions are common in detrital scheelite grains in stream sediments close to the primary mineralisation. The studies of these inclusions in detrital material revealed similar features to those of fluid inclusions from the primary rocks (Mikulski and Kozłowski, 2001). In grains fluvially transported more $2 \mathrm{~km}$ from their bedrock source, the following features were observed. All of the coarse-grained scheelite loses its glassy lustre and takes on a matt surface appearance. In the fine fraction, numbers of scheelite grains with adamantine lustre decrease. The surface of coarse-grained scheelite becomes eroded and covered by beige coatings of clay minerals.

\section{GEOLOGICAL SETTING OF GOLD MINERALISATION FROM THE WAZDROŻE WIELKIE UNIT}

The second study area lies on the crystalline basement of the Wądroże Wielkie unit in the Fore-Sudetic Block (Fig. 6). The crystalline rocks form isolated hills that contrast only slightly with

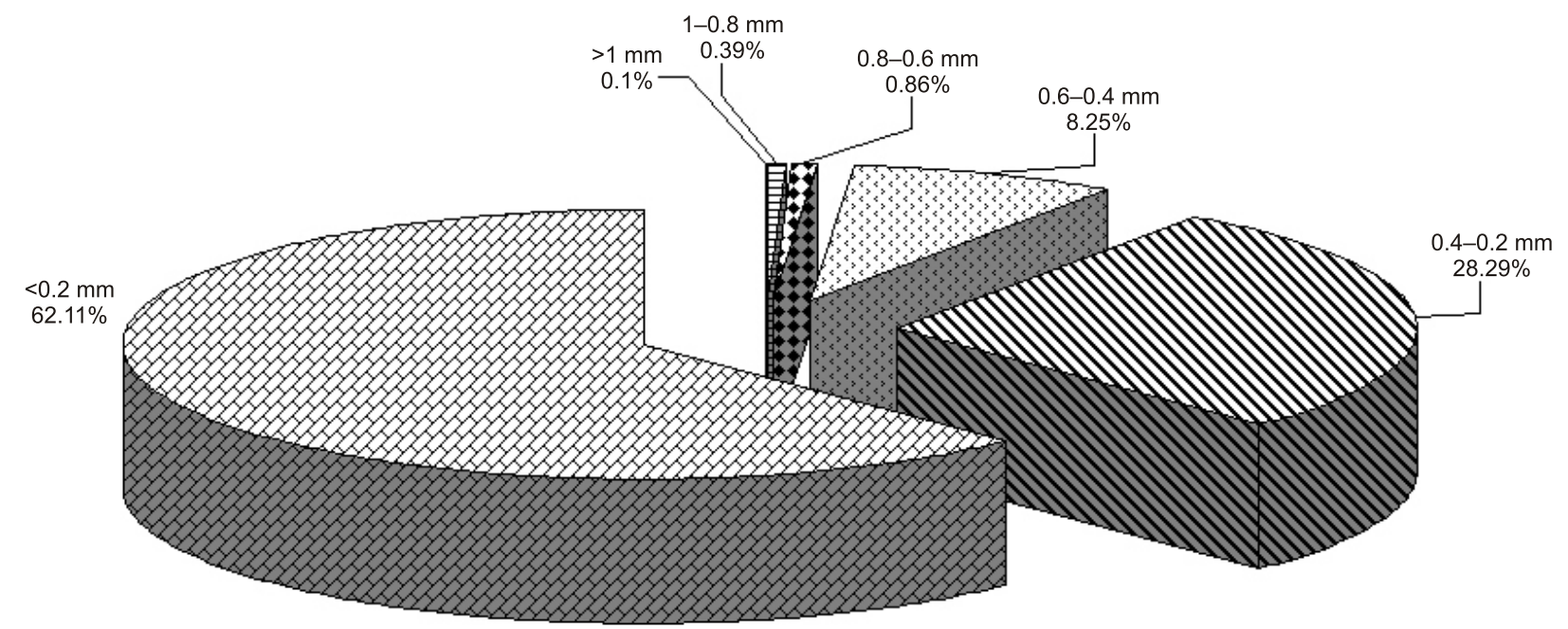

Fig. 4. The percent share of scheelite grains within fractions of detrital samples $(n=22)$ from the upper parts of the Brodek River near Droszków 


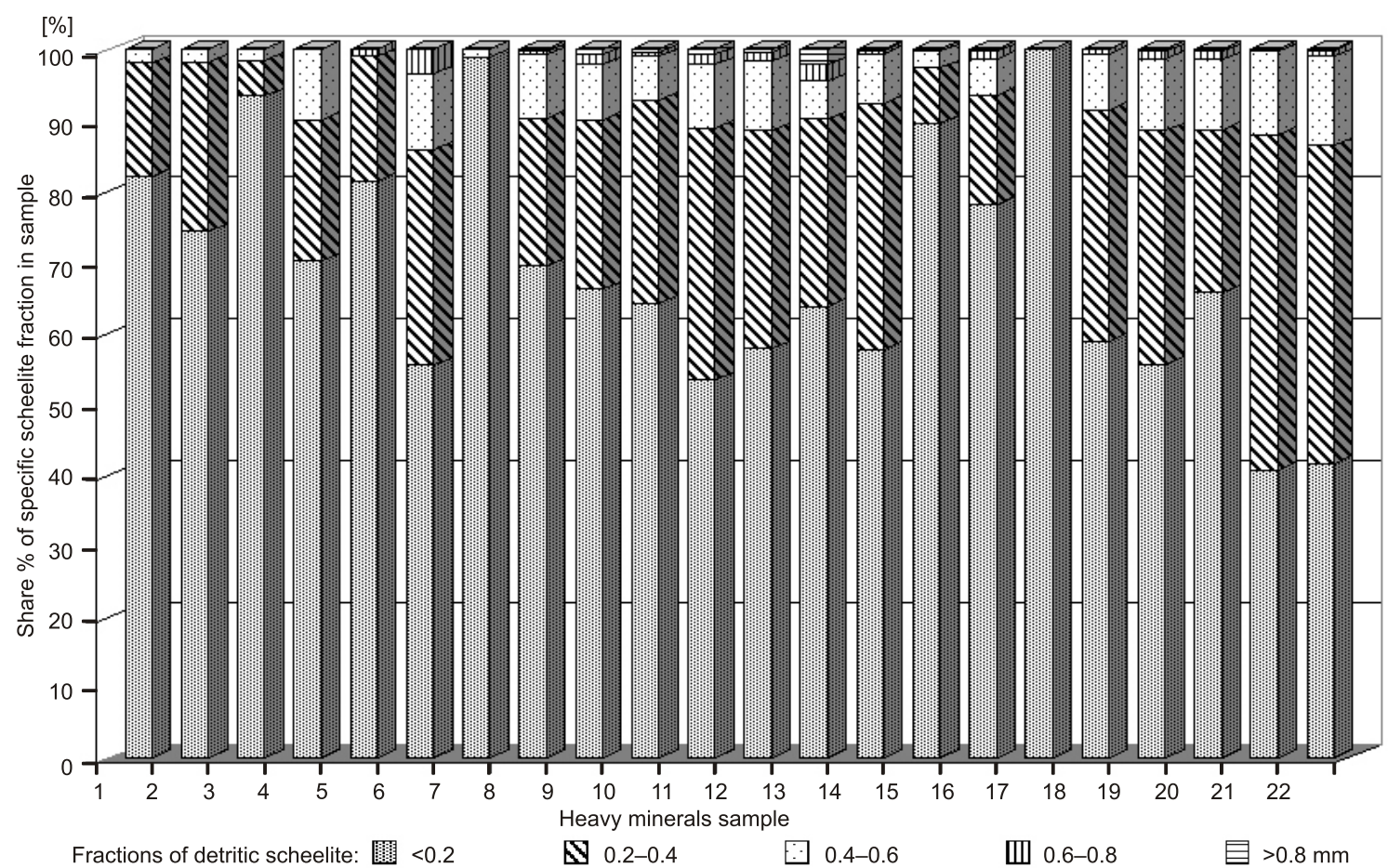

Fig. 5. Histograms of the \% scheelite in specific size fractions of heavy mineral samples in the upper part of the Brodek River study area

the gentle landforms of the region. Selective chemical weathering, controlled by tectonics, has led to formation of an etch plain-type landscape, partly buried under the Cenozoic strata (Badura et al., 2004). The Wądroże Wielkie unit comprises strongly altered and metamorphosed Neoproterozoic and Lower Paleozoic sedimentary and volcanic rocks. These include coarse- and medium-grained gneisses, quartz-graphite schists, graphitic quartzites, mica-quartz schists and greywackes (Grocholski, 1986). The Waqdroże Wielkie area hosts several auriferous pyrite-bearing quartz veins. The veins dip vertically and strike NW-SE to N-S, are 50 to $250 \mathrm{~m}$ long and a few $\mathrm{cm}$ to a few metres thick. The host rocks are gneisses and variable schists. Native $\mathrm{Au}$ is rare, occurring mostly as sub-microscopic blobs in pyrite in veins hosted by the granite gneisses (Zöller and Heuseler, 1926; Grodzicki, 1966). Fine grains $(<0.2 \mathrm{~mm})$ of gold also occur in pitted, corroded quartz with clay-sized material (Grodzicki, 1964). In the Wądroże Wielkie and the nearby Mikołajowice areas, significant but short-term (1340 to 1370) placer gold mining took place (Dziekoński, 1972). In 1343, during the height of the "gold rush", over 15 thousand gold miners worked here. According to Quiring (1914), weekly production amounted to $\sim 19 \mathrm{~kg}$ of gold. The common belief was that the detrital gold in the Cenozoic strata was derived from the quartz veins in the crystalline basement of this area.

After the Variscan Orogeny, the Fore-Sudetic Block was subject to strong uplift and denudation (Oberc, 1972; Cwojdziński and Żelaźniewicz, 1995). The Cenozoic strata infill only local depressions and consist of thick covers of kaoliniterich weathered rocks and clastic deposits (Berezowska and Berezowski, 1979; Piwocki et al., 2004). Chemical weathering and erosion prevailed in the Eocene and Early Oligocene. In the Neogene, the Wądroże Wielkie Massif was divided by numerous faults into minor grabens and horsts. Basaltic volcanism and degradation of highlands were connected with tectonic ac- tivity at that time. By the end of the Quaternary glaciation, channels of the present-day fluvial drainage system were incised into the basement rocks and eroded debris of the older regoliths and lithoclasts eroded during glacial phases.

\section{PLACER GOLD CHARACTERISTICS OF THE WADROŻE WIELKIE DRAINAGE SYSTEM}

Isolated occurrences of placer gold in the Wądroże Wielkie region occur adjacent to surface exposures of gold-bearing quartz veins. Placer gold is found in eluvium-colluvium sediments and pebbly to sandy gravels (alluvia) distributed over ca. 5 $\mathrm{km}$ distance along the Wierzbiak River valley (Fig. 6). These local occurrences have various gold concentrations, and differ in grain size and morphology of the gold particles (Wierchowiec, 2010). To determine the relationship between the gold placers and their primary sources, gold grades were compared with the grain size, shape and chemical composition of the gold particles.

Gold grades range from trace to $0.12 \mathrm{~g} / \mathrm{m}^{3}$. The maximum Au concentration was found at the base of gravel layers. In general, the gold grain size varies between 0.03 and $1.5 \mathrm{~mm}$. The average grain size of gold in different placers varies between 0.23 and $0.66 \mathrm{~mm}$ (Fig. 7). The average size of gold throughout the entire placer field along the Wierzbiak River valley is $0.42 \mathrm{~mm}$. Study of the morphology of placer gold grains from eluvial and colluvial profiles and comparison with those from the stream-channel sediments allowed for the following conclusions related to their gravitational/mechanical transport in eluvial sediments, gold occurring predominantly as crystal intergrowths (aggregates) and flaky grains with elements of skeletal growth (Fig. 7A). Most grains lack pits, but may have voids, from which quartz has been removed (Fig. 7B). They are rarely elongated with rounded and folded rims (Fig. 7C). They represent mostly 


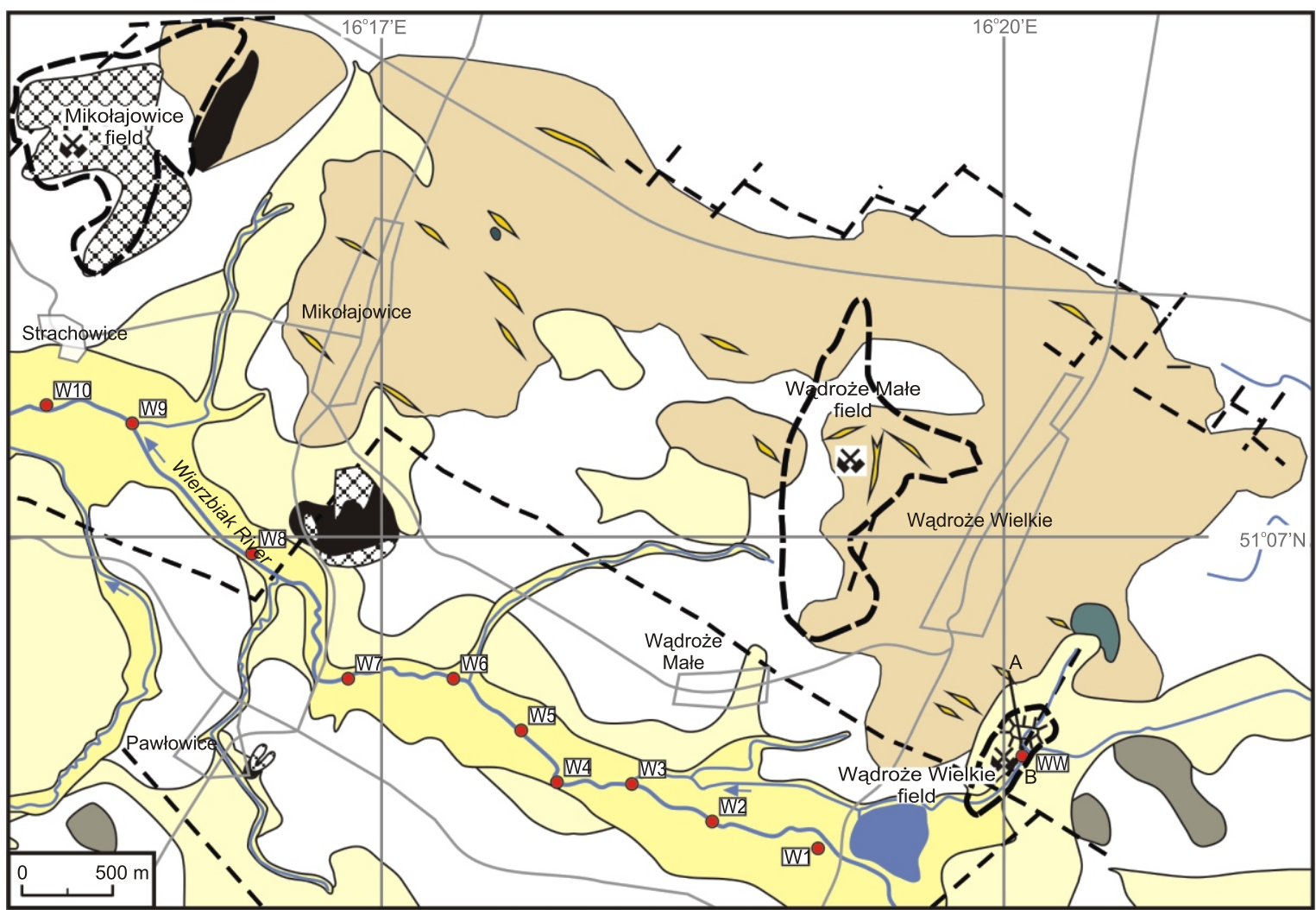

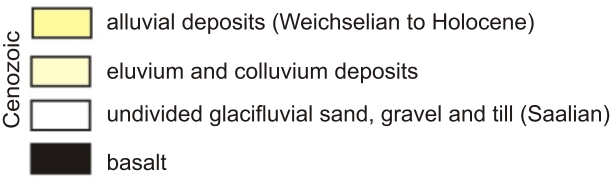

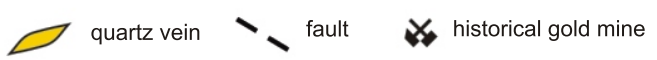

W- sampling site B

cross-section line (see Fig. 7) graywacke schist and phyllites (Devonian?)

Neoproterozoic-Lower Paleozoic

$\square$ amphibolites

granitic gneiss

Fig. 6. Simplified geological map (after Berezowska and Berezowski, 1979) with location of abandoned placer mining areas and sampling sites

subrounded and rounded categories after Power's (1953) classification. The flatness index (F.I. after Cailleux, 1945) for the total gold grain population sampled from the Wądroże Wielkie area ranges from about 2 to 15 , with a predominance of grains with F.I. maxima $<10$ (Fig. 8A). An increase in F.I. is observed for the gold particles from the Wierzbiak River alluvial sediments as progressive hammering increases, which points to increasing flattening for increasing size (x-axis length) of the grain (Fig. 8B). The opposite was observed in eluvial gold where gold grains become less flattened as their size increases (Wierchowiec, 2010). Gold grains have a preserved "ore" appearance with only partially corroded surfaces showing a metallic lustre. In colluvial sediments gold particles show smoothing and blunting of the surfaces and development of etch pits covering particle surfaces (Fig. 7B). A few crystal intergrowths with non-porous metallic surfaces and individual flat, rounded gold grains were also found. Gold particles are free from quartz, but common intergrowths of gold grains with detrital minerals (e.g., rutile) and mica-clay strongly suggests the xenomorphic nature of gold in the host rock. In alluvial sediments, most gold grains are coarser (up to $1.5 \mathrm{~mm}$ in size) compared with the eluvial-colluvial sediments. The grains are commonly blunt with rounded and folded rims, devoid of inter- or overgrowths of other minerals and may have a network of voids.

Detailed SEM investigation of internal textural features of detrital gold grains from the various sediments showed that, despite the differences in morphology described above, a number of them show internal zonation ranging from relatively silver-rich cores to virtually silver-free rims. Rims are either conformable with the grain margin or irregular. Both styles of Ag-depleted rims show sharp boundaries, separating the bulk of the grain from the depleted rim. Similar features were reported for gold from elsewhere in the Lower Silesia region (Banaś et al., 1985; Wierchowiec, 2007, 2010). Internal heterogeneity in the zoned particles is clearly visible in polished sections (in reflected light or SEM back-scattering; Fig. 9) and was quantified by EPMA analysis.

Most gold particles from the alluvial sediments have, in addition, irregular interconnected pits and canals, predominantly at the margins of the grains. This suggests that this gold was subject to deep supergene alteration. In the upper part of the placer deposit, where gold grains still have relicts of their primary morphology, the gold already bears evidence of deep corrosion and leaching, with high-purity rims varying in thickness 


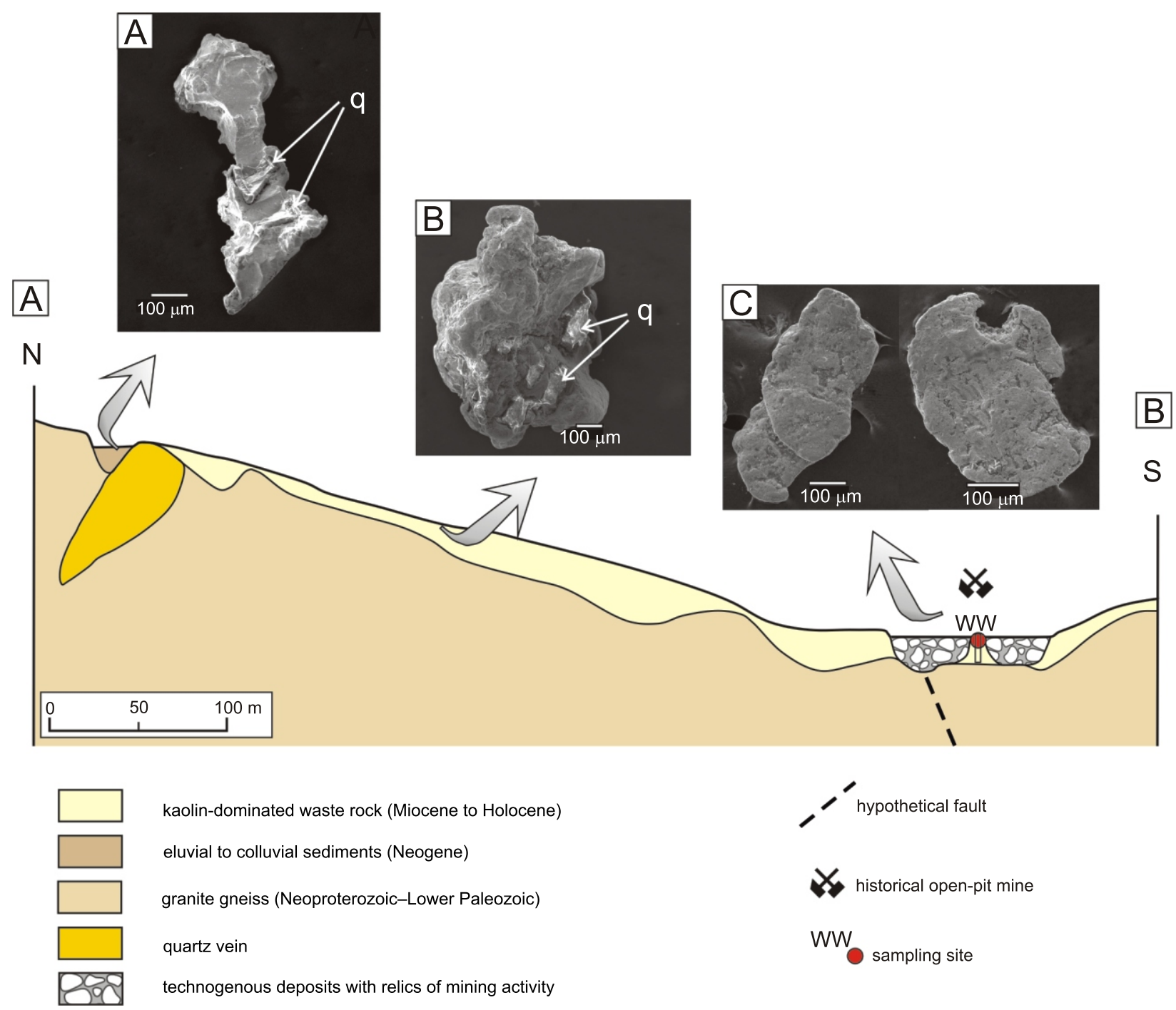

Fig. 7. Schematic cross-section of the Wądroże Wielkie placer field (compiled after Wierchowiec, 2010) showing the location of panned samples collected from eluvial, colluvial and alluvial deposits

Inserts of secondary electron micrographs show different shapes and morphologies of detrital gold from various clastic sediments: A - typical angular gold grain from eluvial gravels with preserved "ore" appearance and only partially corroded surface (note trapped quartz-clay inclusions - q); B - subrounded lobate particle of gold from colluvial sediments with random dissolution pits and irregular canals; $\mathbf{C}$ - typical flaky gold grains: flattened particle showing evidence of intense hammering and rounding

within 5-20 $\mu \mathrm{m}$ (Fig. 9A). In the lower part of the placer, where the extent of supergene alteration of gold is much greater, most of the gold grains have rims thicker than 10-20 $\mu \mathrm{m}$ or are nearly completely pure gold (Fig. 9B). The purity of the rims expressed in terms of fineness ranges between 984 and 1000, while that of the cores ranges between 773 and 884 (Wierchowiec, 2010). Some porous "pure" gold grains (fineness >995; Fig. 9C) were derived probably from reworked pre-existing placers or were formed during Neogene weathering. These porous high fineness gold grains constituted only 1 to $2 \%$ of the gold. Therefore, the source of gold in the study area is likely to be related to local bedrock sources in the Wierzbiak River catchment basin.

\section{DISCUSSION}

This study of detrital scheelite and gold in Cenozoic clastic sediments from the Sudetes and Fore-Sudetic Block documents several physical features which may potentially be a useful tool in mineral exploration. A combined study of the morphology of scheelite and gold grains makes possible the evaluation of their changes resulting from mechanical transport. In the case of the detrital scheelite from the Brodek River, which is draining southern slopes of the Ptasznik metamorphic cover on the Variscan KZS Granitoid Pluton, it was possible to identify primary schee- 

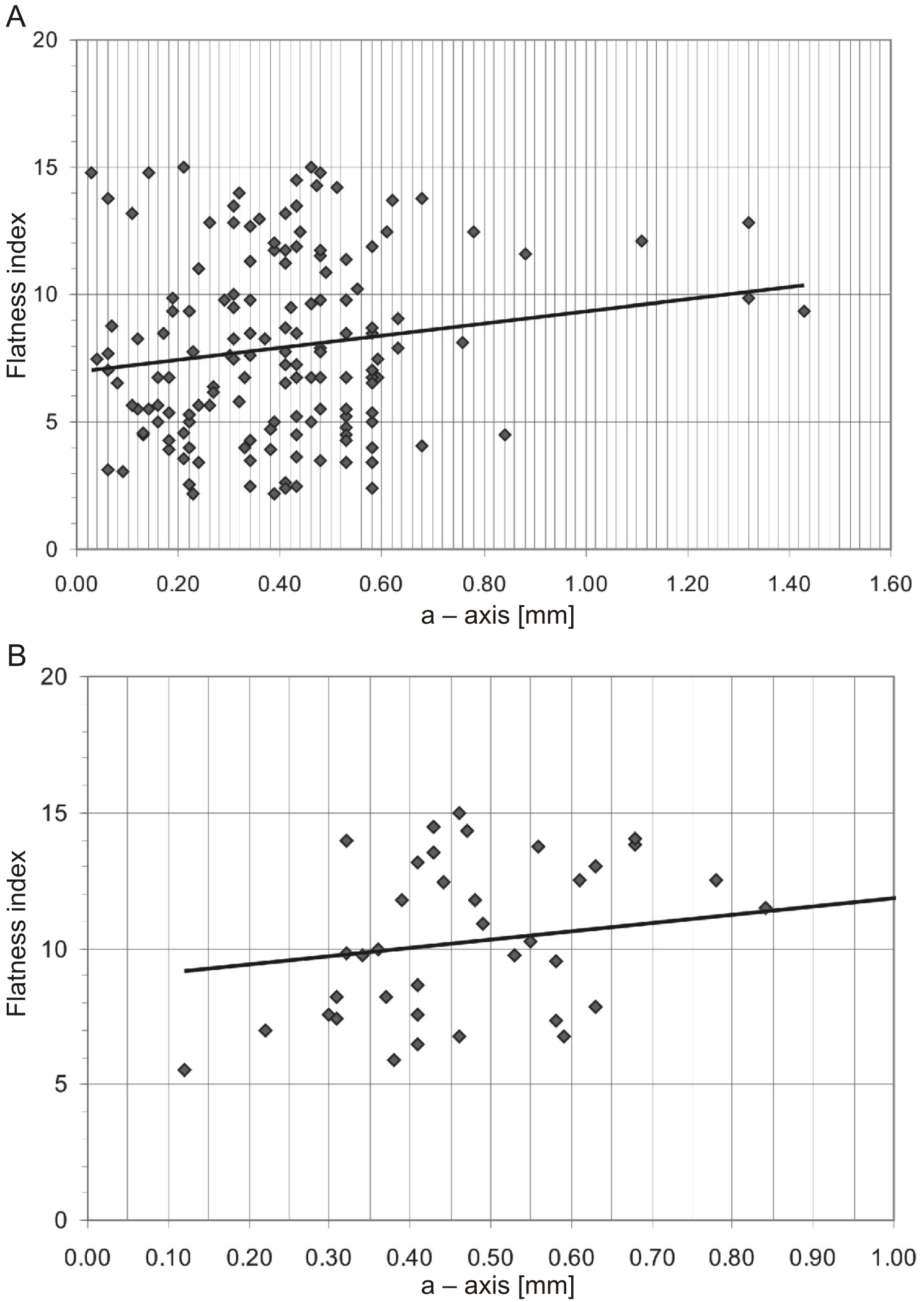

Fig. 8A - Cailleux flatness index for the total gold grain population from the Wądroże Wielkie area; B - from the Wierzbiak River valley 

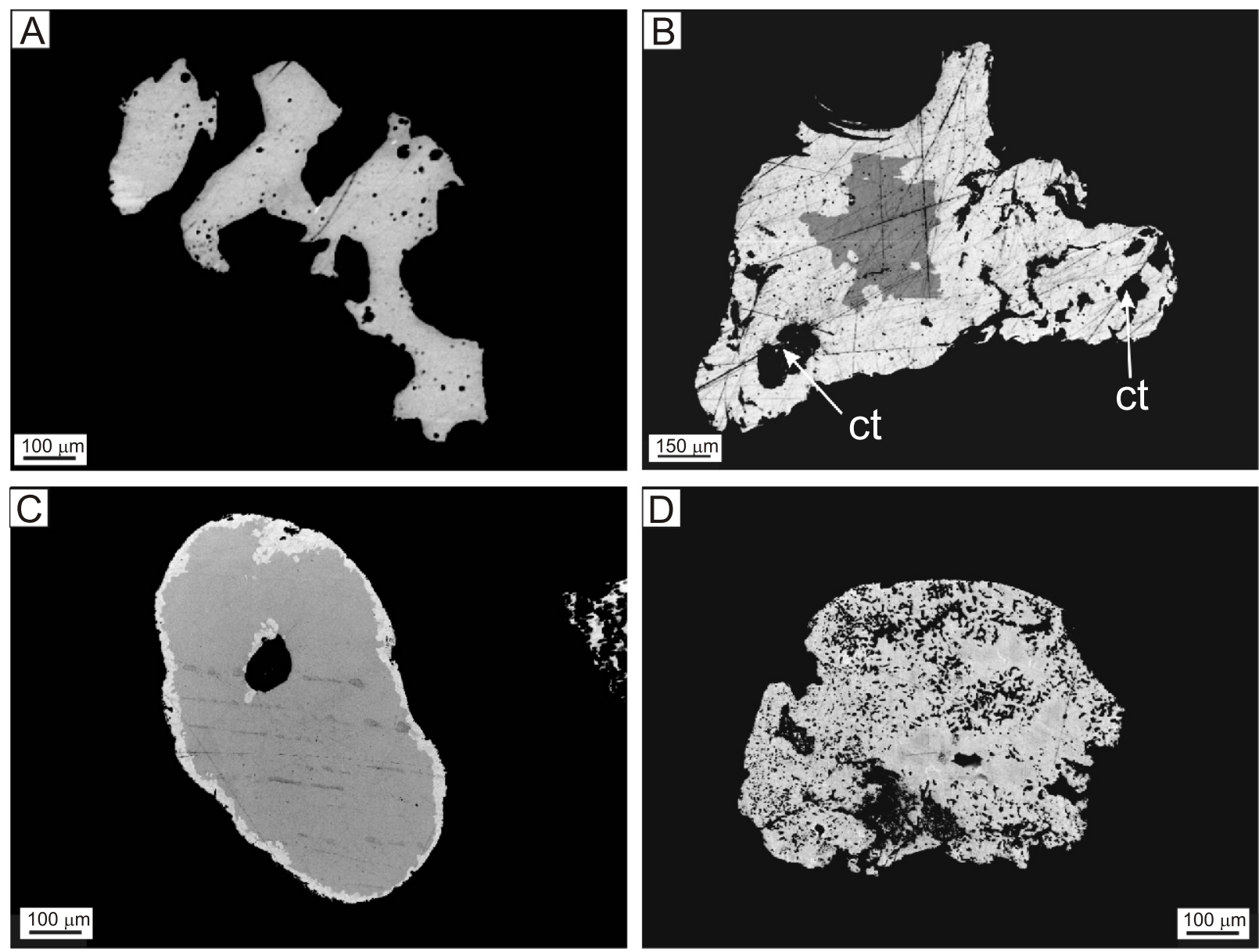

Fig. 9. Back-scattered electron images of placer gold grains showing intragranular texture and chemical heterogeneity on polished sections of particles; the lighter the tone the higher the fineness (gold content)

A - angular grain with high Ag content and no marked core to rim Au/Ag variation (no Ag-free rim), eluvial deposits, sample WW; B - subrounded typical primary Ag-rich grain core (dark gray) surrounded by Ag-poor rim (light gray), note the sharp core-rim contact, figure also shows how smearing of the rim can form a cavity (ct), alluvial deposits, sample W1; C - rounded gold particle with well-defined core of electrum (dark grey) surrounded by high purity Au rim (light grey); alluvial deposits, sample W4; D - rounded high purity gold particle with characteristic sponge-like texture, note the irregular pits, corroded cavities and channels that coalesce to form dendritic networks, sample W9; sample locations are shown in Figure 6

lite-titanite mineralization of vein and disseminated types. Coarse grains of scheelite (>1.0 $\mathrm{mm}$ in size) with characteristic sharp edges occur only near the outcrops of the primary tungsten mineralization. Due to the low hardness and brittle nature of the scheelite, it disintegrated during mechanical transport in the stream (Stendal, 1978). Very small grains $(<0.1 \mathrm{~mm})$ of scheelite are almost completely absent in panned concentrates because material was lost during panning and hydrodynamic effects that transport the smallest grains far from the source area as suspended load (Saxby and Fletcher, 1986).

Scheelite concentration in alluvial sediments of the Złote Mountains is subeconomic. Only placers with scheelite concentrations from hundreds to thousands of grams per cubic metres of alluvial have economic value (e.g., in Russia from 1000 to $\left.2000 \mathrm{~g} / \mathrm{m}^{3}\right)$. In Spain, scheelite $(0.1-3.0 \mathrm{~mm}$ size) concentration in active alluvial sediments around tungsten deposits is a few $\mathrm{g} / \mathrm{m}^{3}$. In these areas and up to $1.5 \mathrm{~km}$ from the outcrops of primary mineralisation, scheelite grains are $<1.0 \mathrm{~mm}$ in size and the total concentration of scheelite decreases to $<1 \mathrm{~g} / \mathrm{m}^{3}$ (Fernandez-Turiel et al., 1992). In the western parts of the Nizke Tatra Mountains of Slovakia, scheelite content in pan concentrates of 5 to $50 \mathrm{~g} / \mathrm{m}^{3}$ were considered as anomalous and subject to more detailed prospecting to find the primary bedrock source (Pecho, 1983). Summarizing the findings within stream-channel sediments, angular and coarse-grained scheelite $(>1 \mathrm{~mm}$ in size) indicates proximity $(<1 \mathrm{~km})$ to outcrops of primary scheelite mineralisation.

Our study of detrital gold grains from eluvial-colluvial and alluvial sediments of the abandoned placer gold deposits near the Wadroże Wielkie leads to several conclusions about the supergene mobility and post-depositional reprecipitation of the gold. The features of the detrital gold suggest that the process of gold deposition in the stream sediments involved several cycles and that the high-purity gold was concentrated earlier. It is likely that the primary sources of gold for the Wierzbiak River placers are eluvial and colluvial sediments covering the Wądroże Wielkie gneisses. During the period of erosion and downcutting along the valley in the Late Pleistocene, gold was redeposited from the auriferous eluvium-colluvium and probably also from older Cenozoic placers. The occurrence, distribution and composition of the gold evolved during the weathering of the fresh auriferous rocks. Weathering of granitic gneisses released gold grains from mineralised veins into the weathering cycle. Mechanical and chemical reworking of gold particles ren- 
dered them progressively smaller, rounded and pitted as the weathering advanced (Figs. 7 and 8). Most alluvial gold grains encountered in the heavy mineral sands from the Wierzbiak drainage system are blunt with rounded and folded rims and may have a network of voids. The gold grains are devoid of inter- or overgrowths of other minerals. The study reveals that placer gold is coarser-grained in the upper course of the Wierzbiak River valley than in the eluvial-colluvial horizons (up to $1.5 \mathrm{~mm}$ in size), and occurs predominantly as flat, semi- and moderately rounded particles (Wierchowiec, 2010). The morphology of gold grains from the middle course of Wierzbiak River is similar to that of gold from the upper part of the placer. However, there is a significant increase of flaky forms (Fig. 7C) and a higher degree of roundness, with moderately rounded and even well-rounded grains present in the large size fractions. Some of the gold particles show marks of slight pressure and abrasion, due to which numerous quartz, clay and Ti-mineral inclusions are overprinted by surrounding gold grains. Rarely, the large gold grains are lobate or irregular, with worm-like gold overgrowths. Most of the fine $(<0.2 \mathrm{~mm})$ gold grains are flaky, with a minor proportion of 3D particles.

According to the distribution of silver in the gold grains, there are two categories of gold grains: (1) zoned gold, with a remarkable core-to-rim zonation and variable silver content throughout, and (2) homogeneous gold. Homogeneous gold grains from all horizons are typically porous and chemically purified without pronounced intra- or inter-particle variation in fineness (Fig. 9D), but some of eluvial gold particles are homogenous Au-Ag alloys devoid of pores (Fig. 9A).

Commonly, $\mathrm{Ag}$ and other metals alloying with gold are leached and dispersed in the geological environment while $\mathrm{Au}$ may be dissolved, transported and reprecipitated. Weathered gold grains show a higher fineness and have rims or veinlets of pure gold around a core similar in composition to that of the primary gold (e.g., Hérail et al., 1990; Varajăo et al., 2000).

The gold is largely residual in origin with variable contributions from secondary Au precipitation. Changes of the initial morphology of gold grains are related not only to deformation but also to the overgrowth of authigenic gold, which forms protrusions in voids of purified spongy grains or worm-like films on the relic gold grain surfaces. Some porous gold particles with a spongy appearance and inner irregular cavities filled with fine-grained supergene minerals may have formed during the post-depositional stage and are strictly authigenic in origin.

Acknowledgements. The authors would like to thank B. McClenaghan and A. Wygralak for their constructive comments that greatly improved our manuscript.

\section{REFERENCES}

Badura J., Przybylski B., Zuchiewicz W. (2004) Cenozoic evolution of Lower Silesia, SW Poland: a new interpretation in the light of sub-Cenozoic and sub-Quaternary topography. Acta Geodynamica et Geomaterialia, 1 (3/135): 7-29.

Banaś M., Grodzicki A., Salamon W. (1985) Mineralogic-geochemical characterization of detrital native gold from the vicinity of Złotoryja and Wądroże Wielkie, Lower Silesia, SW Poland. Mineralogia Polonica, 16 (1): 97-106.

Berezowska B., Berezowski Z. (1979) Szczegółowa mapa geologiczna Sudetów w skali 1:25 000, arkusz Wądroże Wielkie. Państwowy Instytut Geologiczny, Warszawa.

Boyle R.W. (1979) The geochemistry of gold and its deposits (together with a chapter on geochemical prospecting for the element). Geological Survey of Canada Bulletin, 280.

Cailleux A. (1945) Distinction des galeas marines et fluviatiles. Bulletin de la Société Géologique de France, 15: 375-404.

Chapman R.J., Mortensen J.K. (2006) Application of microchemical characterization of placer gold grains to exploration for epithermal gold mineralisation in regions of poor exposure. Journal of Geochemical Exploration, 91:1-26.

Chapman R.J., Leake R.C., Moles N.R. (2000) The use of microchemical analysis of alluvial gold grains in mineral exploration: experiences in Britain and Ireland. Journal of Geochemical Exploration, 71: 241-268.

Cwojdziński S. (1977) Szczegółowa mapa geologiczna Sudetów w skali 1:25 000, arkusz Trzebieszowice. Państwowy Instytut Geologiczny, Warszawa

Cwojdziński S., Żelaźniewicz A. (1995) Podłoże krystaliczne bloku przedsudeckiego. Przewodnik LXVI Zjazdu PTG: 11-27, Wrocławska Drukarnia Naukowa, Wrocław.

DiLabio R.N.W. (1990) Classification and interpretation of the shapes and surface textures of gold grains from till on the Canadian Shield. Geological Survey of Canada Paper, 90: 323-329.

Dill H.G., Klosa D., Steyer G. (2009) The 'Donauplatin': Source rock analysis and origin of a distal fluvial Au-PGE placer in Central Europe. Mineralogy and Petrology, 96 (3-4): 141-161.

Dziekoński T. (1972) Ore mining and working of nonferous metals in Lower Silesia (Poland) from the 13th to the 20th century (in
Polish with English summary). PAN Instytut Historii Kultury Materialnej 4: 249-258. Ossolineum, Wrocław.

Fernandez-Turiel J.L., Duran M.E., Querol X., Lopez-Soler A (1992) Comparison between analytical and mineralometric methods in regional scheelite exploration. Journal of Geochemical Exploration, 43: 205-211.

Giusti L. (1986) The morphology, mineralogy, and behavior of fine-grained gold from placer deposits of Alberta: sampling and implications for mineral exploration. Canadian Journal of Earth Sciences, 23: 1662-1672.

Grocholski A. (1986) The Proterozoic and Palaeozoic in the south-western Poland in a light of a new data (in Polish with English summary). Biuletyn Instytutu Geologicznego, 355: 7-29.

Grodzicki A. (1963) Gold-bearing sands in the environs of Złotoryja (in Polish with English summary). Archiwum Mineralogiczne, 24 (1/2): 239-289.

Grodzicki A. (1964) Wyjaśnienie źródła i genezy okruchowych złóż złota w okolicach Legnickiego Pola - Mikołajowic - Wądroża Wielkiego. Wszechświat, 1: 21-22.

Grodzicki A. (1966) Auriferous sands from Legnickie Pole Mikołajowice - Wądroże Wielkie (in Polish with English summary). Archiwum Mineralogiczne, 26 (1/2): 473-497.

Grodzicki A. (1969) The genesis and composition of the gold-bearing sands of Lwówek Śląski and Bolesławiec area (in Polish with English summary). Acta Universitatis Wratislaviensis, Prace Geologiczno-Mineralogiczne, 86 (2): 99-129.

Grodzicki A. (2011) Placer gold in Sudetes Mountains and in their foreland. Archivum Mineralogiae Monograph, 2: 191-208.

Hallenstein C.P., Pedersen J.L., Stendal H. (1981) Exploration for scheelite in East Greenland - a case study. Journal of Geochemical Exploration 15: 381-392.

Hérail G., Fornar G., Viskarra G., Miranda V. (1990) Morphological and chemical evolution of gold grains during formation of a polygenetic fluviatile placer: the Mio-Pleistocene Tipuani placer example (Andes, Bolivia). Chronique de la recherche minière, $\mathbf{5 0 0}$ : 41-49.

Kanasiewicz J. (1982) A method of quantitative interpretation of schlichs alluvial anomalies on the example of gold (in Polish with English summary). Przegląd Geologiczny, 30 (8): 404-406. 
Kanasiewicz J., Jarmołowicz-Szulc K., Jęczmyk M., Mikulski S. Z., Nawrocka-Miklaszewska M., Ryll A., Sylwestrzak H. (1990) Opracowanie regionalnych map szlichowych geochemicznych Sudetów w aspekcie poszukiwań surowców mineralnych. Zdjęcie szlichowe i geochemiczne aluwialne na arkuszu mapy 1:100 000 Kłodzko (M-33-XVII-58). Narodowe Archiwum Geologiczne, Warszawa. Nr NAG 260/91.

Knight J., Morrison S., Mortensen J. (1999) The relationship between placer gold particle shape, rimming, and distance of fluvial transport as exemplified by gold from the Klondike District, Yukon Territory, Canada. Economic Geology, 94: 635-648.

Loen J.S. (1995) Use of placer gold characteristics to locate bedrock gold mineralisation. Exploration and Mining Geology, 4 335-339.

Lorenc M. (1994) Role of basic magmas in the granitoid evolution (in Polish with English summary). Geologia Sudetica, 28: 3-112.

Mikulski S.Z. (1996) Gold mineralisation within contact-metamorphic and shear zones in the "Golden Creek" quarry - the Złoty Stok Au-As deposit area (Sudetes). Geological Quarterly, 40 (3): 407-442.

Mikulski S.Z. (1998) Gold-bearing ore mineralisation from Bardo Śląskie (Central Sudetes) (in Polish with English summary). Przegląd Geologiczny, 46 (12): 1261-1267.

Mikulski S.Z. (1999) Scheelite and gold-bearing mineralisation in the Ptasznik roof pendant, Sudetes, Poland. In: 5th SGA meeting and 10th Quadrennial IAGOD meeting, August 22-25, 1999 (eds. Stanley et al.): 393-396. A.A.Balkema, London.

Mikulski S.Z. (2000) Prospecting of scheelite and gold mineralisation in the Ptasznik roof pendant of the Kłodzko Złoty Stok intrusion in the Sudetes Mts. (in Polish with English summary). Biuletyn Państwowego Instytutu Geologicznego, 391: 5-88.

Mikulski S.Z. (2005) Geological, mineralogical and geochemical characteristics of the Radzimowice Au-As-Cu deposit from the Kaczawa Mountains (Western Sudetes, Poland) - an example of the transition of porphyry and epithermal style. Mineralium Deposita, 39 (8): 904-920.

Mikulski S.Z. (2007) The late Variscan gold mineralisation in the Kaczawa Mountains, Western Sudetes. Polish Geological Institute Special Papers, 22: 1-162.

Mikulski S.Z. (2011) Gold mineralisation of the Kłodzko-Złoty Stok intrusion contact zone, Sudetes, SW Poland. Archivum Mineralogiae Monograph, 2: 27-43.

Mikulski S.Z., Kozłowski A. (2001) The origin conditions of primary and detrital scheelite related to the Variscan granites in the Central Sudetes (SW Poland). In: Mineral Deposits at the Beginning of the 21 st Century (eds. A. Piestrzynski et al.): 453-456. A.A.Balkema publishers Lisse/Abingdon/Exton (PA)/Tokyo.

Mikulski S.Z., Speczik S. (2008) Organic and inorganic geochemistry of gold mineralisation at the Zloty Stok, SW Poland. Applied Earth Science (Transactions of Institution of Mining and Metallurgy, Section B - Applied Earth Science), 117 (4):149-159.

Mikulski S.Z., Williams I.S., Bagiński B. (2013) Early Carboniferous (Viséan) emplacement of the collisional Kłodzko-Złoty Stok granitoids (Sudetes, SW Poland): constraints from geochemical data and zircon $\mathrm{U}-\mathrm{Pb}$ ages. International Journal of Earth Sciences, 102 (4): 1007-1027.

Nikolaeva L.A., Yablokova S.V. (2007) Typomorphic features of native gold and their use in geological prospecting. Rudy $\mathrm{i}$ Metally, 6: 41-57.

Oberc J. (1972) Sudety i obszary przyległe. Budowa geologiczna Polski. Tom 4. Tektonika, część 2. Wydawnictwa Geologiczne, Warszawa.

Pecho J., ed. (1983) Scheelitovo-zlatonosné zrudnenie v Nizkych Tatrách. Geologický Ústav Dioniza Štúra, Bratislava.
Petersen L.R., Stendal H. (1987) Tungsten exploration in the Valnesfjord Region, Nordland, Northern Norway. Journal of Geochemical Exploration, 29: 151-163.

Piwocki M., Badura J., Przybylski B. (2004) Niż Polski i jego południowe obrzeżenie, neogen. In: Sudety i obszary przyległe. Budowa geologiczna Polski. T. Stratygrafia, część 3a (eds. M. Peryt and M. Piwocki): 71-118. Państwowy Instytut Geologiczny, Warszawa.

Powers M.C. (1953) A new roundness scale for sedimentary particles. Journal of Sedimentary Petrology, 23: 117-119.

Quiring H. (1914) Beiträge zur Kenntnis der niederschlesischen Goldvorkommen. Zeitschrift für Praktische Geologie, 22: 213-222.

Sawicki L., Teisseyre H. (1978) Mapa geologiczna Dolnego Śląska (bez utworów czwartorzędowych) w skali 1:500 000. Zakład Narodowy im. Ossolińskich, Wrocław.

Saxby D.W., Fletcher W.K. (1986) Behaviour of scheelite in a Cordilleran stream. GEOEXPO. Vancouver: 177-183.

Stendal H. (1978) Heavy minerals in stream sediments. SW Norway. Journal of Geochemical Exploration, 29: 183-205.

Tishchenko E.I. (1981) The problem of evolution of gold-flake flattening in alluvial placers. Soviet Geology and Geophysics, 22: 28-33.

Townley B.K., Hérail G., Maksaev V., Palacios C., Parseval P. de, Sepulveda F., Orellana R., Rivas P., Ulloa C. (2003) Gold grain morphology and composition as an exploration tool: application to gold exploration in covered terrain. Geochemistry: Exploration, Environment, Analysis, 3: 29-38.

Varajăo C.A.C., Colin F., Vieillard P., Melfi A.J., Nahon D. (2000) Early weathering of palladium gold under lateritic conditions, Maquiné mine, Minas Gerais, Brazil. Applied Geochemistry, 15: 245-263.

Wierchowiec J. (2002) Morphology and chemistry of placer gold grains - indicators of the origin of placers: an example from the East Sudetic Foreland, Poland. Acta Geologica Polonica, 52 (4): 563-576.

Wierchowiec J. (2006) Preglacial to Holocene auriferous sediments from the East Sudetic Foreland, Poland: gold grade and exploration. Geological Quarterly, 50 (2): 289-302.

Wierchowiec J. (2007) Placer gold and other economic minerals from the remnants of palaeofan deposits in the foreland of the East Sudetes, Poland. Acta Geologica Polonica, 57 (4): 523-537.

Wierchowiec J. (2010) Gold in technogenous placers of Lower Silesia, Poland. Warsaw University Press.

Wierchowiec J. (2011) Placer gold of East Sudetes and its foreland, Poland. Archivum Mineralogiae Monograph, 2: 209-242.

Wierzchołowski B. (1976) Granitoids of the Kłodzko-Złoty Stok massif and their contact influence on the country rocks (petrographic characteristics) (in Polish with English summary). Geologia Sudetica, 11 (2): 3-143.

Wojciechowska I. (1975) Tectonics of the Kłodzko-Złoty Stok granitoides massif and its country rocks in the light of the mesostructural investigation (in Polish with English summary). Geologia Sudetica, 10 (2): 61-121.

Youngson J., Craw D. (1999) Variation in placer style, gold morphology, and gold particle behavior down gravel bed-load rivers: an example from the Shotover/Arrow-Kawarau-Clutha river system, Otago, New Zealand. Economic Geology, 94: 615-634.

Zöller A., Heuseler E. (1926) Die Goldquarzgänge und Goldseifen zwischen Grosswandriss und Wahlstatt in Niederschlesien. Glückauf, 48: 1585-1588. 